\title{
THE POLITICS OF ARABIC NAMING AND ISLAMIZATION IN JAVA \\ Processes of Hybridization and Purification
}

\author{
Askuri*; Joel Corneal Kuipers** \\ *Universitas 'Aisyiyah Yogyakarta, Indonesia; **George Washington \\ University, USA \\ email:asykuri@yahoo.com
}

\begin{abstract}
Arabic names are a component of a changing Islamic discourse in Java. If Arabic names in Java undergo change and growth, then this has implications for changes in Javanese Islam. This research demonstrates the validity of an approach that uses names as a window into Javanese culture. Drawing on a dataset of 3.7 million names analyzed diachronically across 100 years, and using a quantitative method sharpened by ethnography, the analysis of names offers a new way to investigate trends that were previously often difficult to document systematically. In the past, Javanese names usually reflected social classification: santri, abangan, priyayi, or lower and upper class. However, towards the end of the twentieth century, names with class connotations were increasingly abandoned (see Kuipers and Askuri 2017). In this paper we explore further the connection between the decline of class marked names, and the rise of Arabic names. Drawing on data from Askuri (2018), we argue that although the decline of class marked names precedes the sharp rise in the use of Arabic names, the former does not seem to have caused the latter in a simple way. Our data show that in the $20^{\text {th }}$ century, there were two important stages in the Arabisation of Javanese names; 1) an initial "synthetic" stage of one-word blended Javanese Arab names, popular from roughly 1930-1960; 2) a later stage, beginning in 1980, of 2 and 3 word names, one of which was a purified Arabic name. The conclusions have implications for an understanding
\end{abstract}


of the role of bybridity and purification in Javanese Islamic modernity. [Nama-nama Arab merupakan salab satu komponen dari wacana Islam yang dinamis di Jawa. Jika nama-nama Arab di Jawa mengalami perubahan dan pertumbuhan, maka hal ini memiliki implikasi perubahan dalam masyarakat Islam di Jawa. Penelitian ini menunjukekan validitas pendekatan yang menggunakan nama sebagai jendela ke dalam budaya Jawa. Berdasarkan pada dataset 3,7 juta nama yang dianalisis secara diakronis sepanjang 100 tahun, dan menggunakan metode kuantitatif yang dipertajam dengan etnografi, analisis nama menawarkan cara baru untuk menyelidiki trend yang sebelumnya sering sulit untuk didokumentasikan secara sistematis. Di masa lalu, nama-nama Jawa biasanya mencerminkan klasifikasi sosial: santri, abangan, priyayi, atau kelas bawah dan atas. Namun, menjelang akbir abad ke-20, nama-nama dengan konotasi kelas semakin ditinggalkan. Dalam makalah ini kami mengeksplorasi lebih lanjut hubungan antara penurunan nama-nama yang berkonotasi kelas rendah yang ditandai dengan munculnya nama-nama Arab. Berdasarkan data dari Askuri (2018), kami berpendapat bahwa meskipun penurunan nama yang berkonotasi kelas rendah mendahului kenaikan yang tajam dalam penggunaan nama-nama Arab, yang pertama tampaknya tidak. menyebabkan yang terakbir dengan cara yang sederhana. Data kami menunjuke.ean bahwa pada abad ke-20, ada dua tahapan penting dalam Arabisasi nama-nama di Jawa; 1) tahap awal "sintesis" dari nama campuran Jawa-Arab dalam satu kata, yang populer dari sekitar 1930-1960; 2) tahap selanjutnya, dimulai pada tabun 1980, yang tersusun dari 2 atau 3 kata, dimana salah satunya ialab nama Arab yang dimurnikean (purified Arabic names). Kesimpulan ini memiliki implikasi dalam pemahaman tentang peran hibriditas dan pemurnian dalam modernitas Islam di Jawa.]

Keywords: Arabic names, politics of naming, bybridization, Islamic ummah, Java

\section{A. Introduction}

There is an amusing story circulating about a boy in rural Java named "Dmitry Seklitunov." Hearing his name, many Javanese in the village were curious: perhaps his father or mother was Russian, or of Russian descent? They wondered; or, perhaps his parents were diplomats who has served in Russia?; or, possibly he studied in Russia?; or, maybe he was an Indonesian migrant worker who worked in Russia? All these speculations, 
however, were incorrect: his father was a motorcycle taxi driver, while his mother was an herbalist. The name "Dmitry Seklitunov" derives from syllables taken from a variety of sources: his mother's name "Sadmi;" and his father's name"Triyono;" his birthday which was Saturday, November 7th, which fell on the Javanese day "Kliwon" (called "Setu Kliwon" in Javanese). All of these words (the name of his father and mother, and the day) came together to form: (Sa)DMI TRY(ono) SE(tu) KLI(won) (pi)TU NOV(ember). Thus, this becomes DMITRY SEKLITUNOV. For short, he was called "Demit," which means "ghost."

This example illustrates an important feature of naming in contemporary Java: personal names are increasingly including foreign sounds, are increasingly unique, and even longer than before. In the last 100 years, there have been many changes in naming children among Javanese communities. While much has been written by scholars about the structure, form, meaning and use of Javanese names (Koentjaraningrat ${ }^{1}$, Widodo $^{2}$, Suharno $^{3}$, Suranto $^{4}$, Uhlenbeck $^{5}$, Kuswa $^{6}$ ), the studies of how patterns of naming fit into the political and cultural history of Java are not so easily found.

The function of names in Java began to change in the $20^{\text {th }}$ century. In the past, as everywhere, names were used to label individuals, but they

1 Koentjaraningrat, Kebudayaan Jawa (Jakarta: Balai Pustaka, 1994).

2 Sahid Teguh Widodo, "Kajian Kes Nama Orang Jawa di Surakarta: Dinamik dan Sistem", Ph.D. Dissertation (Kedah: Universiti Utara Malaysia, 2010); Sahid Teguh Widodo, Nuraini Yussof, and Hisham Dzakiria, "Nama Orang Jawa: Kepelbagaian unsur dan maknanya", SARI: Jurnal Alam dan Tamadun Melayu, vol. 28, no. 2 (2010), pp. 259-77; Sahid Teguh Widodo and Kundharu Saddhono, "Petangan Tradition In Javanese Personal Naming Practice: An Ethnoliguistic Study”, GEMA Online Journal of Language Studies, vol. 12, no. 4 (2012); Sahid Teguh Widodo, "Konstruksi Nama Orang Jawa: Studi Kasus Nama-Nama Modern di Surakarta.”, Humaniora, vol. 25, no. 1 (2013), pp. 82-91. 1987).

3 A. Soeharno, Sistem Nama Diri dalam Masyarakat Jawa (Yogyakarta: Depdikbud,

4 A. Suranto, Studi Tentang Sistem Nama-Nama Jawa (Surakarta: Fakultas Sastra UNS, 1983). 1978).

${ }^{5}$ E.M. Uhlenbeck, Studies in Javanese Morphology (The Hague: Martinus Nijhoff,

${ }^{6}$ Endah Kuswa, Makna Nama Orang Jawa: Kajian Semantike (Yogyakarta: Fakultas Sastra UGM, 2006). 
were also used to "classify" people into categories. ${ }^{7}$ The way in which one labeled one's child offered a way for others to identify the child socially, in terms of gender, but also in terms of class. The bestowal of a name was (and to some extent still is) regarded as a sacred duty that, if done incorrectly, could have spiritual and even health consequences for the child. If the parents gave a name to the child that did not "fit" with the child, the child could become ill, have bad luck, or suffer from other misfortunes, a condition diagnosed by folk medicine practitioners as kabotan jeneng 'a heavy name.'

All over Europe and in North American, the names bestowed upon children began to become less concentrated. The number of people who shared a common name began to decline in the $19^{\text {th }}$ century. While once there were many people who shared the name "Mary", or "John," the numbers began to decline as parents sought to bestow names that individualized their children as unique persons. Thus at the same time that the concentration of names declined, the percentage of the population with unique names began to increase. ${ }^{8}$

In Java, this tendency manifested itself much later, in the mid to late twentieth century, as our data demonstrated that names functioned less to classify, or group people together so much as a way of differentiating and identifying them as unique individuals. ${ }^{9}$ In Java, in the $19^{\text {th }}$ and early $20^{\text {th }}$ centuries, the way in which names classified people were primarily linked with social class and gender. ${ }^{10}$ Names for girls were typically marked with suffixes " $i$ " while boys" names typically ended in " $-a$ ". According to Uhlenbeck, the names which deemed appropriate for the lower classes (peasants) were usually a simple name with suffix "-em" or "-en" for females, or "-an", "-in", or "-un" for males. ${ }^{11}$ If the social class of peasants give noble names to their children, then the children will Press, 1966).

${ }^{7}$ Claude Lévi-Strauss, The Savage Mind (Chicago: University Of Chicago

${ }^{8}$ Stanley Lieberson, A Matter of Taste: How Names, Fashions, and Culture Change (New Haven: Yale University Press, 2000).

${ }^{9}$ Joel C. Kuipers and Askuri, "Islamization and Identity in Indonesia: The Case of Arabic Names in Java”, Indonesia, no. 103 (2017), pp. 25-49.

${ }^{10}$ E.M. Uhlenbeck, "Systematic Features of Javanese Personal Names", Word, vol. 25, nos. 1-3 (1969), pp. 321-35.

11 Ibid., p. 335. 
suffer kabotan jeneng 'a heavy name', ${ }^{12}$ thought to cause illness and social suffering.

Since the Javanese communities are classified into 3 sub-cultures: Santri, Abangan, and Priyayi, ${ }^{13}$ these social classifications are also reflected in Javanese naming. The Abangan families usually give suitable names derived from Javanese days for their children (like Senen or Pahing), or simple names, such as Sidin or Sirin. The Priyayi families usually give names such as Bambang or Joko, along with additional names for their sons. Santri families usually give Arabic names for their babies, like Mubammad, Abdul, or Siti, along with additional names. ${ }^{14}$

As Uhlenbeck has stated, names which are considered eligible for the lower classes (peasant) are usually simple names that end in "-em" or "-en" for women, or "-an", "-in", or "-un" for men. ${ }^{15}$ Javanese parents also know which names to give their children according to social class. A peasant, for example, would not be given a name that ends with "-kusuma", "-tanaya", or "-ningrat". These names are only fitting for the Javanese priyayi. A peasant would not feel comfortable giving these names to their children, not only because of the fear of being ridiculed by their entire village, but also because there is a belief that such a name would bring bad luck to their children because it is "too heavy" for them (in Javanese it is called "kaboten jeneng"). ${ }^{16}$

Although the phrase kaboten jeneng 'heavy name' is occasionally still heard in Javanese villages, often as a way of enforcing traditional norms of naming behavior, our data show that Javanese names are in fact changing rapidly. But while Javanese names are becoming increasingly Arabic in character, ${ }^{17}$ this has occurred in the context of a robust trend towards hybridization. In what follows, we elaborate on our previous

12 C. Poensen, "lets over Javaansche naamgeving en eigennamen [On Javanese Nameselection and Proper Names]", Mededeelingen van wege het Nederlandsche Zendelinggenootschap, vol. XIV (1870), pp. 304-21.

13 Clifford Geertz, The Religion of Java (London: Free Press of Glencoe, 1960).

14 Ibid., pp. 47-8.

15 Uhlenbeck, "Systematic Features of Javanese Personal Names", p. 339.

16 Poensen, "lets over Javaansche naamgeving en eigennamen [On Javanese Nameselection and Proper Names]".

17 Kuipers and Askuri, "Islamization and Identity in Indonesia". 
findings ${ }^{18}$ to show how this process of hybridization unfolded initially as single word, Arab-Javanese blends, followed later by two and three word names consisting of purified Arabic, Javanese and Westernized names. We then discuss how this process of "purification" has implications for understanding Javanese conceptions of Islamic modernity.

This article is part of a research project on Linguistic Piety sponsored by the National Science Foundation under Prof. Joel Kuipers's supervision, and which became one of the chapters in my dissertation at Gadjah Mada University. This research combines quantitative and ethnographic research collected from three selected districts in central, north and east Java: Bantul, Lamongan and Lumajang, to examine the change of male and female names in the last hundred years. Data on residents' names are obtained from the Population and Civil Registry in the three districts, complete with date of birth, gender, religion, education level, parent's name, and other valuable information, totaling approximately 3.7 million names.

The selection of these three districts is based loosely on the colonial era tripartite classification of the Javanese speaking region into 1) "Vorstenlanden" (Dutch 'kingdom'), or the old Javanese sultanate, represented here by Bantul; 2) Pesisir (Javanese 'north coastal area') represented here by Lamongan; 3) and the "Oosthoek" (Dutch: "East End") represented here by Lumajang. ${ }^{19}$ Cutting across these regions are the dichotomous social classifications between santri and abangan. ${ }^{20}$ Lamongan is often associated with a center of of santri culture, ${ }^{21}$ while while Bantul is situated in inland Java (Mataraman/Nagarigung) and is associated with Kejawen, a form of syncretist Muslim Islam sometimes labeled Abangan.22

\section{Ibid.}

19 Heather Sutherland, "Notes on Java's Regent Families: Part I", Indonesia, no. 16 (1973), pp. 113-47; Heather Sutherland, "Notes on Java’s Regent Families: Part II", Indonesia, no. 17 (1974), pp. 1-42.

${ }^{20}$ Geertz, The Religion of Java.

21 Nur Syam, Islam Pesisir (Yogyakarta: LKiS, 2005).

22 Koentjaraningrat, Kebudayaan Jawa; M.C. Ricklefs, Polarising Javanese Society: Islamic and Other Visions, c. 1830-1930 (Singapore: NUS Press, 2007), pp. 84-105; Robert W. Hefner; Geger Tengger: Perubahan Sosial dan Perkelabian Politik (Yogyakarta: LKiS, 1999). 
Lumajang is one of the areas of Tanah Sabrang Wetan ${ }^{23}$ or the Eastern End, ${ }^{24}$ which was the last Hindu site in Java that was Islamicized due to colonial policy in organizing plantation laborers from Madura. ${ }^{25}$ Although the current political and cultural map has changed with the many phenomena of cross-cutting affiliations, the phenomenon of the local people's language from these three regions is still felt.

To code and analyze this large data set, we developed a piece of software to help us identify and label names according to their ethnic origin and type. The names were categorized by language origin: Java, Arabic, and European. Of course, with the growing number of children's names in Java becoming increasingly hybrid, a mixed-name category became necessary: Javanese-Arabic, Indonesian Hybrid (mixed names of Indonesian or non-Javanese tribes), and Superhybrid (a Javanese-ArabicEuropean). In the end, we were able to classify and encode nearly the entire dataset, after repeating the coding several times by entering the new name identifiers.

\section{B. Arabic Names as an Islamic Register in Java}

As in the Muslim world in general, the adoption of Arabic names in Java is associated with membership and affiliation with Islamic beliefs. ${ }^{26}$ In the context of Indonesia, although there has been no comprehensive analysis on the history of Arabic names in Indonesia, Arabic names have always accompanied the history of Islam in the archipelago. Hikajat Raja-Raja Pasai (The History of Pasai Kings) narrates that the founder of the Islamic kingdom of Samudera Pasai in Sumatra (Indonesia), Mirah Silu, changed his name to an Arabic name "al-Malik al-Salib" when he

23 Koentjaraningrat, Kebudayaan Jawa.

24 Sutherland, "Notes on Java's Regent Families"; Sutherland, "Notes on Java's Regent Families".

25 Kuntowijoyo, Perubahan Sosial dalam Masyarakat Agraris: Madura, 1850-1940 (Yogyakarta: Mata Bangsa, 2002).

26 Tahera Qutbuddin, "Arabic in India: A Survey and Classification of Its Uses, Compared with Persian", Journal of the American Oriental Society, vol. 127, no. 3 (2007), pp. 315-38; Richard W. Bulliet, Conversion to Islam in the Medieval Period: An Essay in Quantitative History (Cambridge: Harvard University Press, 1979); Nader Habibi, "Popularity of Islamic and Persian Names in Iran before and after the Islamic Revolution”, International Journal of Middle East Studies, vol. 24, no. 2 (1992), pp. 253-60. 
embraced Islam. ${ }^{27}$ The same thing happened in other Islamic kingdoms in the archipelago, as seen in the names or titles of kings which contain an Arabic name: i.e. Sultan.

Although there is still a lot of debate about the history of Islam in the archipelago, in its development, Islam grew rapidly in most parts of the archipelago, making Indonesia one of the largest Muslim countries in the world. Along with the development of Islam in the archipelago, Arabic names are also increasingly becoming a part of the expression of Islam.

Not all Muslims in Indonesia have Arabic names; people who have Arabic names in Indonesia are almost certainly Muslims. Only a few who have Arabic names are not Muslim. This suggests that Arabic names are almost synonymous with Islamic identity. At least, this research dataset shows that nearly one hundred percent of people who have Arabic names in three research areas are Muslims. Only a handful of non-Muslims have Arabic names.

\section{The Dynamics of Naming in Java}

In contrast to the earlier studies of Javanese onomastics, ${ }^{28}$ this research gives full attention to the historical dynamics of naming. Some previous analyses of Javanese names focused on specific aspects of the historical development of names. Sahid Teguh Widodo, for example,

27 Elizabeth Lambourn, "Tombstones, Texts, and Typologies: Seeing Sources for the Early History of Islam in Southeast Asia", Journal of the Economic and Social History of the Orient, vol. 51, no. 2 (2008), pp. 252-86; Christopher H. Wake, "Malacca's Early Kings and the Reception of Islam", Journal of Southeast Asian History, vol. 5, no. 2 (1964), pp. 104-28; P.L. Amin Sweeney, "The Connection between the Hikayat Raja2 Pasai and the Sejarah Melayu", Journal of the Malaysian Branch of the Royal Asiatic Society, vol. 40, no. 2 (212) (1967), pp. 94-105; E.U. Kratz, "Hikayat Raja Pasai: A Second Manuscript", Journal of the Malaysian Branch of the Royal Asiatic Society, vol. 62, no. 1 (256) (1989), pp. 1-10.

28 Koentjaraningrat, Kebudayaan Jawa; Widodo, "Kajian Kes Nama Orang Jawa di Surakarta: Dinamik dan Sistem"; Sahid Teguh Widodo, "Modernization of Javanese Personal Names in the North Coastal Region of Java Indonesia", Asian Journal of Social Sciences \& Humanities, vol. 2, no. 4a (2013), pp. 42-9; Soeharno, Sistem Nama Diri Dalam Masyarakat Jawa; Suranto, Studi Tentang Sistem Nama-Nama Jawa; Kuswa, Makna Nama Orang Jawa: Kajian Semantik; Widodo, "Konstruksi Nama Orang Jawa: Studi Kasus Nama-Nama Modern di Surakarta."; Uhlenbeck, "Systematic Features of Javanese Personal Names"; Uhlenbeck, Studies in Javanese Morphology. 
reviewed the modernization of names in the north coast of Java, ${ }^{29}$ Surakarta, ${ }^{30}$ and Java in general. ${ }^{31}$ Hadiwidjana also briefly reviewed "the new model names" in Java in the 1960s. ${ }^{32}$ But, unfortunately, these studies stop short of understanding the changing patterns of linguistic feature in Javanese names, and never explain why the changes in patterns happened in their political and cultural context.

\section{The Dynamics of Naming in Bantul}

Some anthropological studies in Java mention that the Mataraman region, including Vostenlanden (Solo and Yogyakarta: Bantul included in it) is the home of Abangan Muslims. ${ }^{33}$ Javanese culture in this region is rooted in the tradition of the palace, which is characterized by a highly syncretic religious life, and mixed elements of Hinduism, Buddhism, and Islam. ${ }^{34}$ The rise of the mysticism movement was ever marked by the existence of Kejawen in the region. Mataraman regions that are close to the center of power of Java (the royal palace), called Negarigung, affecting the outlook of naming in other areas in Java: Pasisir, Mancanagari, and Tanah Sabrang Wetan. ${ }^{35}$

With anthropological context reviewed by previous scholars, the naming in the region also reflects an image that is almost the same as the previous reviews made by anthropologists. However, the studies underwent a dramatic change in the late 1980s or early 1990s, as shown below in the description of the following statistics:

29 Widodo, "Modernization of Javanese Personal Names in the North Coastal Region of Java Indonesia”.

30 Widodo, "Konstruksi Nama Orang Jawa: Studi Kasus Nama-Nama Modern di Surakarta."

31 Sahid Teguh Widodo, "Nama Orang Jawa Kontemporer", Haluan Sastra Budaya, vol. 29, no. 4 (2011).

32 R. Hadiwidjana, Nama-Nama Indonesia (Yogyakarta: Spring, 1968), p. 159.

33 Koentjaraningrat, Kebudayaan Jawa; Robert W. Hefner, Islam Pasar Keadilan: Artikulasi Lokal, Kapitalisme, dan Demokrasi, trans. by Amirudin and Asyhabuddin (Yogyakarta: LKiS, 2000); M.C. Ricklefs, A History of Modern Indonesia since c.1300 (Stanford: Stanford University Press, 1993).

${ }^{34}$ Koentjaraningrat, Kebudayaan Jawa.

35 Ibid. 


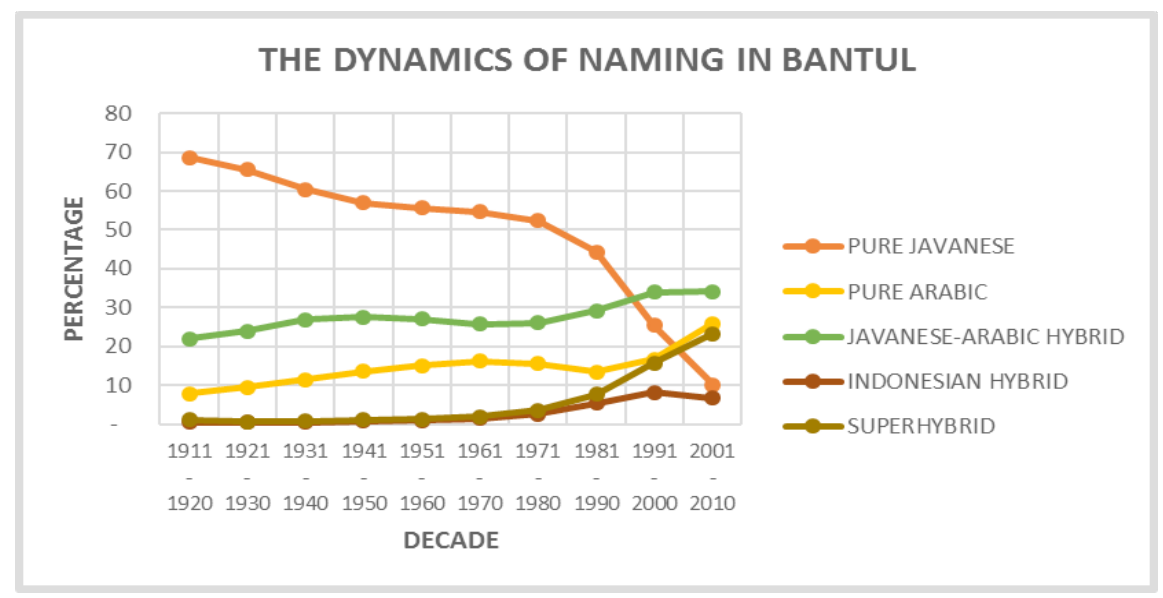

Figure C.1. The Dynamics of Naming in Bantul

From the statistical description above, between the years 1911 1980, pure Javanese names ranked highest in Bantul (in every decade in this period over $50 \%$ of the population have pure Javanese names). As Bantul was part of the "Vorstenland" ("kingdom") area, this is consistent with previous anthropological analyses showing that the region is a home of Kejawen, a mystical, and uniquely Javanese variety of religious practice. However, in the transition from the 1980s into the 1990s, pure Javanese names drop drastically in this region, and approach its nadir at ten percent at the beginning of the 21st century. Pure Arabic names crept up to twenty-six percent during the same period. At the same time, Javanese-Arabic hybrid names also crept up to thirty-four percent. Meanwhile, Indonesian hybrid and superhybrid names, which until the 1970s were not used by many Javanese people, experienced a growth in the late 1980s. Specifically, superhybrid names have grown sharply since the beginning of the 21st century.

Before 1990s, when pure Javanese names were dominant compared to other categories of names, Bantul was once a home of Kejawen or Abangan, as anthropological assumptions of the 1960s. However, with the fall of pure Javanese names dramatically since the turn of the 1980s to the 1990s, the people in these regions is indicated experience religious orientation change. This will be discussed later in this chapter.

Some of the statistical descriptions above also confirm another 
conclusion: in the transition from the 1980s to the 1990s, there was a dramatic change in Javanese naming, where pure Javanese names declined dramatically, while at the same time, Arabic names and hybrid names (Javanese-Arabic hybrid, Indonesian hybrid, and superhybrid) increased. Among the categories of names that are increasing dramatically are superhybrid names, which are hybrid names consisting of three or more languages, especially Javanese-Arabic-other foreign names.

\section{The Dynamics of Naming in Lamongan}

Javanese people in the region of Nagarigung and Mataraman generally assume that Javanese culture, known as Pasisirculture, flourished in the cities of the North Coast of Java. The area includes the IndramayuCirebon area in the West, and the town of Gresik in the East. Pigeaud suggested the division of Pasisir regions into three sub-sections: (1) sub-western, covering Cirebon, Tegal and Pekalongan; (2) sub-central, covering Kudus, Demak and surrounding areas; and (3) sub-eastern, centered in Gresik. ${ }^{36}$ However, Java itself only distinguishes itself into two sub-sections: (1) a sub-western region, based in Cirebon and (2) a sub-eastern region centered in Demak. The Surabaya area is thick with a distinctive accent, and is regarded as a sub-region specific culture. ${ }^{37}$

The residents in the North Coast of Java, in general, embraced a puritan Islam that influenced the socio-cultural context. ${ }^{38}$ Their literature history, which is over four centuries old, also shows a strong Islamic influence. ${ }^{39}$ During the 20th century, various Javanese Islamic reformist movements emerged in the region. Bourgeoisie Javanese culture appeared in the North Coast towns of Java. ${ }^{40}$ There are allegations that the first Javanese pilgrims came from this region. After the Suez Canal was opened in 1869, the departure of pilgrims from Java began to flourish in the

36 Pigeaud, T. G. T., 1967. Literature of Java: Catalogue Raisonné of Javanese Manuscripts in the Library of the University of Leiden and Other Public Collections in the Netherlands. The Hague: Martinus Nyhoff.

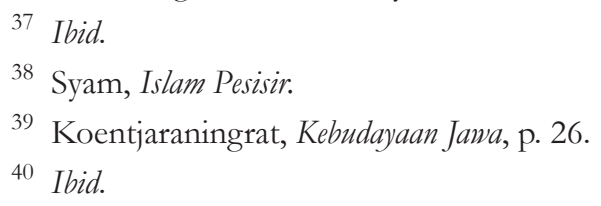


region, especially from Surabaya. ${ }^{41}$ Therefore, Surabaya is the gateway of Islamic reformation ideas, derived from the Islamic centers of culture and intellectuals from the Middle East in Javanese culture.

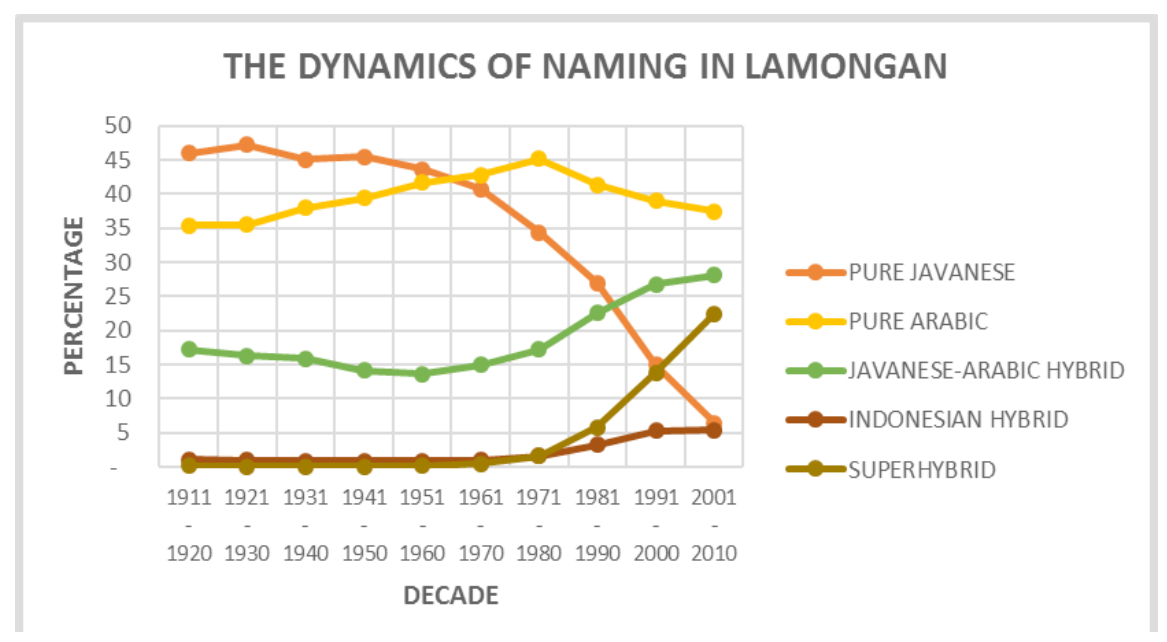

Figure C.2. The Dynamics of Naming in Lamongan

From the statistical description above, during 1911 - 1950, pure Arabic names and pure Javanese names were competing against each other. However, pure Javanese names began shown a decreasing trend since the 1950s, and declining approaching a nadir in the early $21 \mathrm{st}$ century (stayed 6\%), pure Arabic names persisted and had even reached $45 \%$ in the 1970s. Javanese-Arabic hybrid names have shown a sharp upward trend since the 1980s, and until the beginning of the $21 \mathrm{st}$ century had reached twenty-eight percent. It is very impressive that in Bantul, where Superhybrid names, until the 1970s only reached zero to two percent, have increased dramatically since the 1980s, and reached twenty-three percent at the beginning of the 21 st century. It is with the persistence of pure Arabic names for one hundred years, plus previous anthropological reviews, that the Pasisir regions (Lamongan included) find their justification for being called the home of puritan Islam (Santri).

By reflecting the dynamics of pure Arabic names, which remained above thirty-five percent for one hundred years in Lamongan, the Lamongan community still asserts its territory as the birthplace of Santri,

41 Koentjaraningrat, Kebudayaan Jawa. 
as anthropological studies have surmised for decades. As in Bantul, Lamongan also experienced a dramatic transition from the 1980s to the 1990s, in which Superhybrid names have grown significantly.

\section{Dynamics of Naming in Lumajang}

Tanah Sabrang Wetan or Ujung Timur, represented in our study by the regency of Lumajang, is the historic site of the last Hindus in Java, especially in mountainous Tengger ${ }^{42}$ that were Islamized by the arrival of Madura immigrants due to clearing of plantations in the region in the early 19th century. ${ }^{43}$ Residents of low-lying areas between Pasuruan and Panarukan, and lowland areas among volcanoes in East Java such as Jember, are predominantly Madurese, as much as ninety percent. The proportion of these Madurese are reduced on the slopes of the mountains, and to the South of the area, which resulted in the southern city of Jember averaging only twenty percent Madurese. ${ }^{44}$

The proportion of Madurese is high in the Ujung Timur region, as shown in the colonial census of 1930. In that year, more than half of the Madurese population were living in this region. The population census in this year showed that the total population of Madurese was 4,287,276 (including those living in small islands in the east of Madura island). As much as 1,940,567 Madurese people (forty-five percent) live on Madura island, while 2,346,707 (fifty-five percent) traversed across the strait and settled in Java. ${ }^{45}$ In Panarukan, Bondowoso, and Kraksaan residences, most of the population is Madurese. The Madurese population in Kraksaan amounted to 88.3\%. In Probolinggo, Madurese amounted to seventy-two percent, sixty-one percent in Jember, forty-five percent in Pasuruan, $45.6 \%$ in Lumajang, 17.6\% in Banyuwangi, twelve percent in Malang, and $12.7 \%$ in Bangil. They were actively involved in national movement in the city and other neighborhood of ethnic groups of

42 Nancy J. Smith-Hefner, "A Social History of Language Change in Highland East Java”, The Journal of Asian Studies, vol. 48, no. 2 (1989), pp. 257-71; Hefner; Geger Tengger.

43 Kuntowijoyo, Perubahan Sosial dalam Masyarakat Agraris.

44 Ron Hatley, Keanekaragaman Kebudayaan Jawa (Surabaya: Universitas Airlangga, 1978).

45 Kuntowijoyo, Perubahan Sosial dalam Masyarakat Agraris. 
Madurese. ${ }^{46}$

With the Islamic background of Madurese immigrants, and the dominant population of the Ujung Timur region, the naming in the region also reflects an image that is almost the same as previous reviews by anthropologists, especially in regards to the persistence of pure Arabic names for more than one hundred years, as the statistical description below shows:

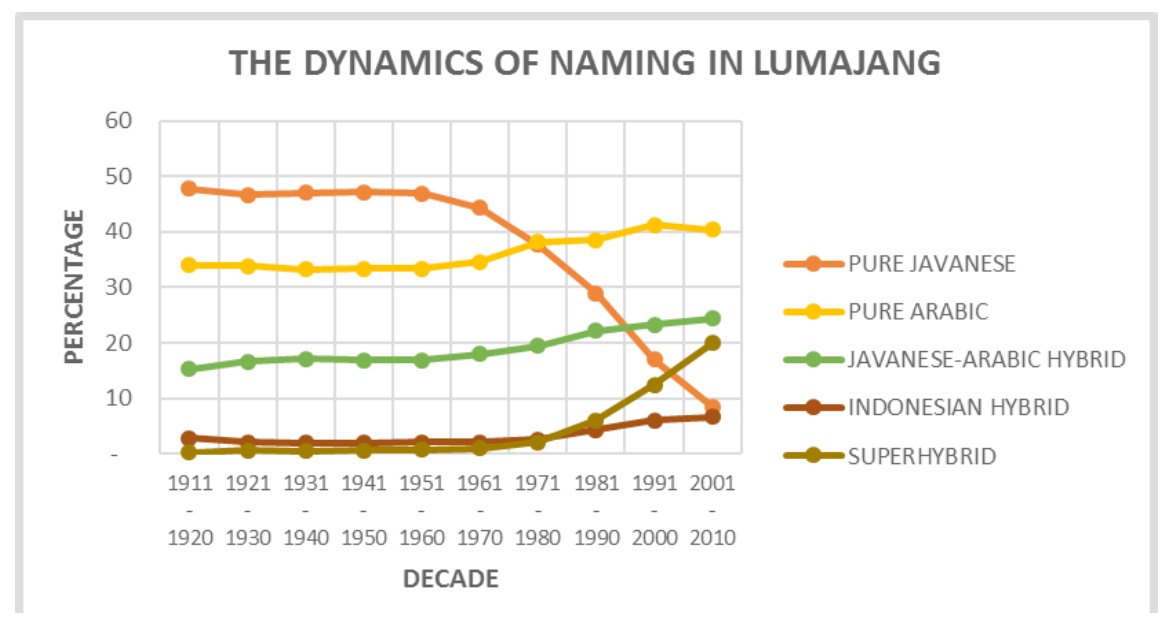

Figure C.3. The Dynamics of Naming in Lumajang

As seen in the statistical graphs above, until the 1970s, pure Arabic names and pure Javanese names were competing, although pure Javanese names were still quite dominant. However, in the 1970s, it changed: pure Arabic names increased, while pure Javanese names decreased. In the next several decades, pure Arabic names increased and will most likely continue to increase, while pure Javanese names have fallen sharply until almost reached a nadir (9\%). While Javanese-Arabic names have showed an upward trend since the 1970s, superhybrid names have also increased dramatically since the 1980s. With the persistence of pure Arabic names for one hundred years, the dominance of Madurese can provide an answer to the persistence of pure Arabic names, because they are, in fact, traditional Muslims.

With the persistence of pure Arabic names in Lumajang for one hundred years above thirty percent, the region exhibits a strong Santri ${ }^{46}$ Ibid. 
tradition, mainly immigrants from Madura. Nonetheless, as in previous research areas, Lumajang also experienced a change: at the turn of the 1980 s to the 1990 s, there was a dramatic change, in which superhybrid names that were previously unknown in the repertory of names in the region experienced dramatic growth.

\section{The Change of Islamic Ummah in Java}

From these figures, it is clear that in the 1980 - 1990's, there was a dramatic change in almost all segments of naming: pure Javanese names dropped sharply; pure Arabic names increased in Bantul, and continue to be prominent in Lamongan and Lumajang; hybrid names have (either Javanese-Arabic hybrid names or superhybrid) increased sharply. Insofar as the use of Arabic names reflects participation in the discourse of Islamic identity, how did this actually take place? The following macroanalysis of the changes of Muslims in Indonesia below are an effort to provide an understanding.

There are at least two important things in the change of Muslims in Indonesia. First, the Santri Muslims grew into a middle class that is different from previous generations of Santri. As already stated above, the middle class Muslims of the 1980s and 1990s had different characteristics from previous generations of Muslims. They are now a self-confident culture, highly educated, and have high purchasing power, growing rapidly in urban areas. This distinguishes them from their predecessors of the 1950s and 1960s, who maintained the widespread colonial-era belief that Muslims were to be traditional, countrified, uneducated, and marginalized in villages, where they were often dubbed as "The Sarungan". ${ }^{47}$ Secondly, nominal Muslims (Abangan) have also become orthodox Muslims. ${ }^{48}$ This makes them different from the previous Abangan generation, who had become a political rival for the Santri. We know that in the 1950s, their parents (nominal Muslims) were the core supporters of PKI, and the left-wing of PNI. The opposition to orthodox Islam was one of the core features that united the lower class. ${ }^{49}$

47 M. Syafi'i Anwar, Pemikiran dan Aksi Islam Indonesia: Sebuah Kajian Politik tentang Cendekiawan Muslim Orde Baru (Jakarta: Paramadina, 1995).

${ }^{48}$ Hefner, Islam Pasar Keadilan.

49 Ibid. 
The changes in the macro-structure of Islamic Ummah, as described above, in turn, affected the micro-structure of Muslim communities, of which an individual's identity is an important factor. As Friedman stated, the individual identity can be divided into two different contexts: the micro-individual identity, and macro-collective/social identity. ${ }^{50}$ In between, there is a relationship of mutual influence. ${ }^{51}$ This relationship between macro and micro is recorded is well documented in the naming process. Although a name is a label of individual identity, the production process involves a larger structure that brings forth a collective identity.

Personal names are one marker of individual identity that are most easily seen. As most linguistic features, a name is composed of words adopted from language. Therefore, the production of personal names always involves a power relation, ${ }^{52}$ in which every child born is always dependent on parents to be named. The personal name is always connected with a greater social structure dimension, because the parents are not standalone entities, but bound in a larger structure that are influenced by the state. In other words, parents' sense of social agency and aspirations to create a world are expressed through naming. ${ }^{53}$

As described above, the production of names among Javanese people is always dynamic where it involves Arabic names. Name production can be seen as a window into Javanese Muslims' families (especially the Muslims' parents), and their interactions with the historical reality of Islam, globalization, modernization, and Indonesian identity.

Naming in Java, as described throughout this chapter, is not entirely derived from Javanese language, but also from Arabic and Europeon languages. As Fairclough stated, the textual construction of names (including the composition of syntax, semantics, and phonology) can lead to a deeper understanding of social relationships, and institutional and

50 Jonathan Friedman, Cultural Identity and Global Process (London: Sage Publications, 2000).

51 Anthony Giddens, Modernity and Self-Identity: Self and Society in the Late Modern Age (Stanford: Stanford University Press, 1991).

52 Michel Foucault, "The Subject and Power", Critical Inquiry, vol. 8, no. 4 (1982), pp. 777-95.

53 Pierre Bourdieu, Language and Symbolic Power, ed. by John Brookshire Thompson (Cambridge: Polity Press, 1991). 
ideological dimensions in the production process, as well as its reception. ${ }^{54}$ Therefore, the linguistic construction of Javanese personal names can also be seen as an expression of Javanese identity. Anthropologically, the textual construction of Javanese children names did not experience many dramatic changes until the $1970 \mathrm{~s} ;{ }^{55}$ or having suffix "-em" or "-en" for women, or "-an", “-in", or "-un" for men. ${ }^{56}$

In Indonesia, there have been several shifts in political power, starting from the colonial period, Japanese imperialism, the proclamation of independence, the Old Order, the beginning of the New Order. During these periods, the textual construction of names among Javanese people did not change much. In Bantul, pure Javanese names were still dominant until the 1970s. In Lamongan and Lumajang, pure Arabic names were relatively stagnant, in the range of about forty percent over the last one hundred years. Meanwhile, Javanese-Arabic hybrid names stablized in the third region until the 1970s.

During major milestones in the history of this nation, no dramatic changes in the textual construction of Javanese childrens' names occurred until the 1970s. Although Bahasa Indonesia had already been declared a language of unity through the Youth Pledge (Sumpah Pemuda) since 1928, and the dream of an independent country was materialized through the Declaration of Independence in 1945, Javanese children's names did not necessarily become more Indonesian. Only a few people were named "Merdekawat" or "Mahardika," for example (as examples of patriotic names commemorating independence), and even then, the names were used more as a marker of time, such as the fact that the child was born in August, when the Indonesian people commemorate Independence Day.

However, Muslims experienced a change during the late 1980s and early 1990s, as described earlier in this discussion. The textual construction of the Javanese childrens' names experienced dramatic changes: pure Javanese names declined dramatically, while the JavaneseArabic hybrid names, and Indonesian hybrid names relatively increased. Most notably, superhybrid names grew dramatically; that is, names which were a mixture of textual constructed Javanese-Arabic-European names.

\footnotetext{
54 Norman Fairclough, Language and Power (London: Longman, 1989).

55 Widodo, Yussof, and Dzakiria, "Nama Orang Jawa".

56 Uhlenbeck, "Systematic Features of Javanese Personal Names".
} 
Parents in Java during the late 1980s, early 1990s, and thereafter, have created a change in identity for their children. After experiencing a period of growth in higher education, most Muslims in Java then have become part of a new middle class. ${ }^{57}$ Higher education has opened opportunities for them to work in the public sectors and other industries, leaving behind their agricultural jobs, which were once the economic basis of their families (parents). Most of them eventually grew into wealthy, affluent, and educated individuals.

Historical context in Indonesia, as expressed at the beginning of this discussion, shows that nominal Muslims became more literate in normative Islamic teachings, which were based on the orthodoxy of Islam. ${ }^{58}$ In the midst of incessant of Islamic propagation through media and civil Islam, and conditioned by the state that were increasingly accommodating to Muslims, the growth of Muslims' educational levels and prosperity in Java are different from the growth of peoples' educational levels and prosperity in Europe. In Western countries, high levels of education tend to go hand-in-hand with the opinions of secularism..$^{59}$ In Java, or in Indonesia in general, high levels of education and wealth would encourage Muslims communities to give more attention to religious observance.

\section{E. The Politics of Naming}

The vertical mobility of Muslim generations in the late 1980s, and early 1990s, encouraged the growth of political identity on a micro-level

57 Mitsuo Nakamura, "The Emergence of Islamizing Middle Class and the Dialectics of Political Islam in the New Order of Indonesia: Prelude to Formation of the ICMI", presented at the Islam and the Social Construction of Identities: Comparative Perspectives on Southeast Asian Muslims (University of Hawaii, 1993); Kuntowijoyo, "Muslim Kelas Menengah Indonesia 1910-1950: Sebuah Pencarian Identitas", Prisma, vol. 11 (1985); Robert W. Hefner, "Islam, State, and Civil Society: ICMI and the Struggle for the Indonesian Middle Class", Indonesia, no. 56 (1993), pp. 1-35; Arif Budiman, "From Lower to Middle Class: Political Activites Beforeand After 1988", in Democracy in Indonesia, 1950s and 1990s, ed. by J.D. Legge and David Bourchier (Clayton, Vic: Centre of Southeast Asian Studies, Monash University, 1994); Douglas E. Ramage, Politics in Indonesia: Democracy, Islam, and the Ideology of Tolerance (New York: Routledge, 1995).

58 Hefner, Islam Pasar Keadilan.

59 Robert Wuthnow, The Restructuring of American Religion: Society and Faith since World War II (Princeton: Princeton University Press, 1988). 
through the naming of their children. As "the politics of onomastics" illustrates ${ }^{60}$ the responsibility of a person to name someone else is "an infinite paradox of narcissism" ${ }^{61}$ and is a vehicle for a generation to become agents in the recognition of self identity and specific subjects. ${ }^{62}$ In this context, generations of Muslims near the end of the 20th century played a political game by naming their children as expresssions of vertical mobility. The decline of traditional, pure Javanese names dramatically demonstrates an affirmation of an identity that is different from the previous generation; that is, an escape from the old Javanese feudal system to a new identity based on equality. If Benedict Anderson described the Independence Proclamation of the Republic of Indonesia as a symbol of the end of the feudalistic system that was maintained by the Colonial Government, ${ }^{63}$ then it does not apply to expressions of identity through naming because there are not many changes that occured in the textual naming construction of Javanese children in the post-1945 period (the 1950s). The effort to escape from the Javanese feudalistic structure occured partly through the naming of Javanese children in the late 1980s and early 1990s. The sons and daughters of Javanese peasants began to obtain higher education and economic prosperity. Since the end of the 20th century, it is rare to find a Javanese child's name that connotes being of the "lower class." The opportunity to develop a better life is through higher education and economic prosperity, not through an elitist political statement.

As Bourdieu recognized, part of one's cultural capacity to act agentively in the world is the capacity to bestow names. ${ }^{64}$ In this way, the generation of Javanese parents at the end of the 20th century tried to create a new world for their children, through naming. When pure Javanese names were not widely used by parents in Java for their

${ }^{60}$ Jacques Derrida, "Signature Event Context", in Margins of Philosophy, trans. by Alan Bass (Chicago: University of Chicago Press, 1982).

61 Jacques Derrida, On the Name, ed. by Thomas Dutoit (Stanford, CA: Stanford University Press, 1995), p. 12.

62 Jacques Derrida, The Politics of Friendship, trans. by George Collins (New York: Verso, 1997), p. 250.

63 Benedict R. O'G (Benedict Richard O'Gorman) Anderson, Java in a Time of Revolution: Occupation and Resistance, 1944-1946 (Ithaca: Cornell University Press, 1972).

64 Bourdieu, Language and Symbolic Power. 
children, many parents used broader linguistic resources to give names to their children. Without abandoning Javanese identity, some parents combined Javanese names with Arabic names, thus forming a series of Javanese-Arabic names. Some combined Javanese names with Arabic and European names, so as to form a series of superhybrid names, while others combinde Javanese names and non-Arabic linguistic resources to form Indonesian hybrid names. Meanwhile, some parents also used Arabic linguistics resources, thus forming a series of pure Arabic names.

Based on the existing dataset, and described in some of the statistical schemes above, many Arabic names are combined with other linguistic resources to compose Javanese childrens' names. If naming can build a new world, ${ }^{65}$ with Arabic names, what kind of world did Javanese parents want to build for their children in the late 20th century?

The changes in naming practices of the Javanese, especially with the increase of Arabic names must be understood in its Javanese sociocultural context. For the Javanese, the name is a mandate; it includes the wills, desires, hopes, or prayers of parents for their children. The use of Arabic names as an Islamic register is an indication that the parents want to link the future of their children to Islam. If the change in naming practices involving Arabic names occurs on a broad scale, it will be difficult to avoid the conclusion that Islamization, which is a process of deepening commitment to the standards of normative beliefs of Islam, practices, and religious identity, is occuring. ${ }^{66}$

However, that is not to say that Islamisation is a simple, onedimensional process. It does not fit easily, for example, with the thesis of the clash of civilization between Islam and the West, where Islam is often assumed to be a monolithic single entity. ${ }^{67}$ Islam in Indonesia is actually fragmented into diverse visions of Islam. The different varieties compete in different political traditions, although in the end, Islamisation has tended to support a democratic civil society. ${ }^{68}$ Islamization in modern

\section{Ibid.}

66 M.C. Ricklefs, Islamisation and Its Opponents in Java: A Political, Social, Cultural and Religious History, c. 1930 to the Present (Honolulu: University of Hawaii Press, 2012), p. 516.

${ }^{67}$ Samuel P. Huntington, The Clash of Civilizations and the Remaking of World Order (New York: Simon \& Schuster, 1996).

68 Hefner, Islam Pasar Keadilan. 
Indonesia refers to a complex process with diverse directions, involving various Muslim groups that do not necessarily agree with one another on many aspects, with no one having full control of the process. ${ }^{69}$

When the knowledge and practice of Islam increasingly becomes an object of interest for an increasing number of people, ${ }^{70}$ Arabic names seem to be a type of representation of capital for a number of people, helping to form a new world for their children. Pure Javanese names, by contrast, are often considered old-fashioned and even tacky by some parents. The Javanese people adopted Arabic names precisely to establish the identity of the younger Javanese generation with Islam, in many different ways.

Throughout the last hundred years, there have been three patterns in the Arabic names used by the Javanese to name their children: (1) Domesticated Arabic Names, i.e. Javanization of Arabic names. For example: the name Muhammad is javanized to Mat, Kemat, Kahmat, Mamat, Muh, Moh, or Simub; or the name Abdurrahman being Bedu Amang or Durokman; or the name 'Aisyah becomes Ngaisah or Asiyab; (2) Purified Arabic Names, i.e. the writing of Arabic names by using a combination of letters or symbols that are close to the original sounds in Arabic, such as Ahmad, Mudhaffar, Khoirun Nisa', 'Aisyah, Muhammad, and others; and (3) Globalized Arabic Names, i.e. Arabic names which use English spelling because such names are considered to be more cosmoplitan, such as the name Aisyah to Aeesha or Ayesha; Amirah becomes Ameera, Raisah becomes Reysha, Tsalitsah becomes Thalitha, and others.

With the three Arabic name patterns that developed in Java, we can explore the layers of historical and social classes in the dialectic of Javanese communities, Javanese tradition, modernity, and globalization. Domesticated Arabic names represent a layer of historical and social class in which the Javanese synthesized two identities, Javaneseness and Islamic, to create a new identity for children. For Ricklefs, the period of approximately 600 years from the 14th century up to the beginning of

69 Ariel Heryanto, Identitas dan Kenikmatan: Politik Budaya Layar Indonesia, trans. by Eric Sasono (Jakarta: Kepustakaan Populer Gramedia, 2015), p. 40.

${ }^{70}$ Hefner, Islam Pasar Keadilan. 
the 19th century was a period he called the "mystic synthesis". ${ }^{71}$ It began to fade with the emergence of polarization among Javanese Muslims between The Abangan and The Putiban, or in terms of Clifford Geertz is the Abangan and the Santri. ${ }^{72}$

The dataset of Javanese names we have been examining however, indicates the continuance of Java-Islam synthesis among the grassroots up to the 20th century, even now, with the different pattern of synthesis. Ricklefs' historical analysis, ${ }^{73}$ with its reliance on elite texts of the palace, ignores the discourse of identity (through naming) which took place at the grassroots level. By delimiting religious polarization in Java to the beginning of the 19th century to the beginning of the 20th century, Ricklef's model ignores the continuing existence of a synthesis of Java and Islam that is still present to this day, although the patterns of synthesis can be different and are always changing in the context of space and time.

As seen through the patterns of naming Javanese children up until the mid 20th century, many names referred to the day and month in the Javanese-Islamic calendar, instituted by Sultan Agung since the 16th century. Ricklefs himself called Sultan Agung a mystical, Javanese King, who had two identities: Javanese and Islamic. ${ }^{74}$ For example: the name Paryudi refers to the Javanese-Islamic calendar, and shows that he was born in Sapar (Arabic: Safar); the name Waljiman refers to the month of Sawal (Arabic: Syawwa); the name Suradi refers to the month of Sura (Arabic: 'Ashura, which is in the month of Muharram); the name Mulyono refers to the month Mulud (Arabic: Mawlud, in Rabi' al-Awwal). Names like these are widely used by the Javanese to serve as a marker of time for when their children were born. Behind the phenomenon of Javanese children's naming are many pre-natal rituals (such as mitoni, tingkeban, procotan, etc.), and post-natal rituals (brokohan, bubur lemu, krayahan, tedhak siten, and others). These rituals forms of Javanese ritual, but combined with the prayers in Arabic, and the traditions of Islam. This is one form of Javanese-Islam synthesis, which continued until the mid-20th century,

71 M.C. Ricklefs, Mystic Synthesis in Java: A History of Islamization from the Fourteenth to the Early Nineteenth Centuries (Norwalk, Conn: EastBridge, 2006).

72 Geertz, The Religion of Java.

73 Ricklefs, Mystic Synthesis in Java; Ricklefs, Polarising Javanese society.

74 Ricklefs, Mystic Synthesis in Java, p. 51. 
amidst the bustle of polarization of Islam which outlasted the elites.

Modernization in Java, as Ricklefs suggested, has dragged the Javanese people into conflicting religious polarizations, many of which harbor significant hazards: putihan, abangan, priyayi, modernists, traditionalists, Sufi, Christian, anti-Islam, supporters of pre-Islamic Javanese culture, Western, and others. ${ }^{75}$ As in the West, modernization has always exhibited purifying tendencies. ${ }^{76}$ Modernization has always tried to maintain a sharp distinction between key binary oppositions; syncretism is thus a form of failed modernism.

However, history does not always run linearly as implied by the standard narratives of modernization. When the Javanese became more educated and prosperous, Javanese-Islam synthesis was not necessarily lost. Some synthetic practices (syncretic) were already lost (due to purification), but the synthesis of Javanese-Islamic identity that remained were maintained through language, especially naming. Although currently, advanced levels of Islamic learning are widely apparent and on display through many Islamic media outlets [give examples of this], Islam is not necessarily the only identity portrayed, as we see more hybridized identities created through naming practices. The naming of Javanese people in the past usually only consisted of one word, then progressively expanded into two words or more, to catalyze, spawn, and create new forms of hybridity.

Javanese-Arabic hybrid names are one of the categories of names in Java which brought about hybridized identities of Javanese children. The growth in this category of names increased from decade to decade in the last one hundred years. As a hybrid name consisted of two elements, Javanese and Arabic, parents actually wanted to give a hybrid identity to their children. Parents wanted to build a new world for their children, by synthesizing two identities simultaneously, i.e. Javanese identity and Islamic identity. In regards to the textual construction of a blend of Javanese-Arabic names over the past one hundred years, there have been two patterns of growth seen in this category. In the first half of the twentieth century, the synthesis of Javanese-Arabic hybrid

75 Ricklefs, Polarising Javanese Society.

76 Bruno Latour, We Have Never Been Modern, trans. by Catherine Porter (Cambridge, Massachusetts: Harvard University Press, 1993). 
names consisted generally of one word, and tended to be patterned after domesticated Arabic names that were a combination of the words or sounds both of Arabic and the Javanese language, and did not have a specific Arabic language meaning associated with Islam or piety. Examples of such names include: Jumingun, Juminah, Markonah, Pargilatun, Sumiyatun, Sumaryatun, Yatun, Miyatun, Sri Yatun, Rusmiyatun, Murnijatun, Saminah, Tuminah, Minah, Tukinah, Sinah, Wakinah, Marjinah, Mustinah, Mujinah, Siti Mursinah, Rukinah, and others.

Anthropologically, the synthesis of Javanese-Arabic hybrid names in the first half of the 20th century, as well as the Javanese name in the lower classes in general, were generated more or less spontaneously, ${ }^{77}$ because names given to babies usually relate to the conditions or circumstances at the time of birth. That is, the name is given after the birth by using a common reference to some widely recognizable, shared event, such as a market day, weather condition. As a result, the concentration of Javanese-Arabic, one word hybrid names is quite high during this period. Although there was a high concentration of Javanese-Arabic blended names in the first half of the 20th century, this does not reflect the parents' growing adoption of orthodox Islam, but rather instead their embrace of indigenous Javanese ideologies about synthesis.

However, in the second half of the 20th century, the textual construction of Javanese-Arabic names evolved into two words, using a combination of Arabic words and Javanese words (or vice versa). The Arabic names tended to be purified Arabic names and had references of clear meaning, like Ahmad Suwandi, Erni Hidayati, Yusuf Waluyo, Edi Nurcabyo, Nur Wijayanti, Tutik Nurbayati, Isti Rohmani, Arif Setiawan, Ratna Fitrianingsih, Fuad Bramantya, Nur Wahyudi, Nur Iswantoro, Saleb Widodo Budi Rabmadi, Hijrahman Budiyanto, Eni Rabmawati, Akbid Rusdiantoso, and others. Although these include a mix of Javanese-Arabic names, the textual construction of Arabic names are increasingly standardized, and use an ever more standard transliteration to represent Arabic sounds.

The two-word Arabic names of Javanese-Arabic hybrid names in the second half of the 20th century indicates an improving Arabic/ Quranic literacy of the parents. In addition, the choices of words selected for the names no longer harbored lower class connotations. Although

77 Koentjaraningrat, Kebudayaan Jawa. 
the realities of lower social classes still existed in Javanese society, parents increasingly sought to avoid giving their children a class-defined label. Reflecting their increasing optimism for education and economic opportunity, parents sought an end to feudalistic labeling, and wanted to provide their children with opportunities to participate in a new, egalitarian world. Therefore, the mix of Javanese-Arabic names which identified a child as lower class became obsolete. Some parents no longer hesitated to use elements of Javanese names that had formerly been reserved for the elite, priyayi class. $^{78}$

As the concentration of names decreased in the second half of the 20th century (i.e. fewer and fewer children shared the same name), the parents' choices also began to show signs of increased individuation. In this period, parents began to develop individual preferences for naming through reference books, magazines, and the internet. Unlike the previous generation, they began to develop individual creativity in assembling Javanese and Arabic names, establishing appropriate names for their children. Preparation of such names begin before the birth of the baby.

While Javanese-Arabic names continue to survive and increase, mixed names including Javanese-Arabic-European names (in this study is referred to as Superhybrid names) have increased sharply since the late 1980s. The combination of Superhybrid names consists of words or sounds (linguistic interference), and a minimum of three lingual elements: Arabic elements, Javanese elements, and European elements. Example: Naura Auryn Nariswari, Selviani Eka Safira, Cinta Bella Fatika Sari, Berlyana Princess Syarofa, Laisya Rabma Viarana Putri, Bianca Nevtamiya Rižkya Putri, Helmi Juni Sugianta, Zaidan Reynard Khairan, Niara Pinilih Tazgya Attaqy, Rofi Dicky Wharrdiyono, Daffarel Farban Zaky Primary, Exsel Firmansyab Putra, Aldy Rizqy Nur Alfian, Rijal Hakim Harvard Sanjoyo, Rafa Alberta Dhaniswara, Brian Zaenal Arif Damar Rasendriya, Stuart Al Fabrezi Arya Gemifa, Gazby Afdhlien Putra Ferischa, Andrea Rizqi Saputra, and others.

Children who were born in the late 1980s or later with Superhybrid names share a similar pattern: the names exhibit a strong sense of confidence, one not burdened with a label of social class. The textual construction of the name tends to be composed of at least three different words, thus it is longer (on average, consisting of three words or more).

${ }^{78}$ Ibid., p. 105. 
Although Arabic names (written in Roman characters) have been steadily increasing, most of the Arabic elements in Superhybrid names continue to be purified Arabic names (standardized Arabic names). Much the same as the Javanese-Arabic names that were common in the second half of the 20th century, the Arabic elements in these longer names also tend to be purified.

By looking at the superhybrid names of children in the $21^{\text {st }}$ century, we may imagine their parents: educated, literate, media-savvy, (relatively) prosperous, with a wide set of associations about the world they live in. To compose a long name that contains three elements or more, parents develop creativity to compose a name through various references. Unlike the previous generation, parents in the $21^{\text {st }}$ century have typically prepared names long before the birth of their babies.

With the increasingly long name series - consisting of three words or more, and composed of three or more linguistic elements - Superhybrid names became increasingly unique, because no person has the exact same name. This is different from the names of the previous generation, of which many were similar. It also indicates that many parents since the 1980s have increasingly celebrated individuation. The decrease of name concentration is in line with the logic of capitalism and consumerism; that is, in a high consumption society, ${ }^{79}$ people can choose consumer goods that are more unique to their own individual identities. Almost similar to consumer goods, as in a modern capitalist society, the name is also a kind of commodity that can be selected, according to individual taste, to build a unique identity. ${ }^{80}$

From the perspective of Javanese parents - who view the name as a hope and expectation for the child's future - the hybridity of Javanese naming contains an implied message: parents weave traditional Javanese naming practices into their childrens' names as a reminder to their children to not forget their Javanese identities. Arabic names are used as a reminder to their children to not forget their Islamic identity, and the Western names are used as a way to remind their children that they will

79 W.W. Rostow, The Stages of Economic Growth: A Non-Communist Manifesto (Cambridge: Cambridge University Press, 1960).

${ }^{80}$ Lieberson, A Matter of Taste; Pierre Bourdieu, Distinction: A Social Critique of the Judgement of Taste, trans. by Richard Nice (Cambridge: Harvard University Press, 1984). 
face a modern and globalized world.

At the same time we see a decrease in pure Javanese names (i.e. names that consist entirely of Javanese words), and an increase in hybrid names, we also have witnessed a continual presence of pure Arabic names. These names continue to be associated with a santri (devoutly Islamic) class, and has made rapid inroads in to regions which formerly associated with Abangan syncretists. However, although these are pure Arabic names, they are different from Arabic names of the Middle East. The pure Arabic names exhibit a diversity of Arabic literacy skills (Quranic literacy) of Muslim communities in Java.

As a form of Islamic communicative competence, ${ }^{81}$ pure Arabic names in Java are thick with Qur'anic nuance, because many pure Arabic names are taken from the words or phrases in the Qur'an. The names are closely related to the Qur'anic literacy, which is one form of communicative competence in Islamic tradition. From the standpoint of literacy, Qur'anic literacy is one form of ideological literacy that saw literacy as a social practice, and is a product of the ideology that developed in the community. ${ }^{82}$

With this ideological approach of literacy, we can see the history of literacy in Indonesia, especially in Java, with a broader, more layered view. Unlike the standard, official state narrative of literacy in Indonesia (colonial and post-independence), literacy in Indonesia generally, and Java in particular, is actually plural. Long before the colonial government applied ethical policies in 1910 that sought to educate the natives (in the field of literacy), Islamic literacy has been longstanding from generations to generations of Muslims in Java. Islamic literacy includes: Qur'anic literacy (which lasted through the teaching of reading al-Quran, recitation/tadarrus, and Qur'anic studies); Arabic literacy (either in Arabic language through the study of Kitab Kuning or in Javanese language with the inscription of Javanese pegon); and Islam literacy in general (which lasted through recitation, or Islamic lectures given in communities).

Islamic literacy qualifies as a form of ideological literacy, a series

81 D.H. Hymes, "On Communicative Competence", in Sociolinguistics: Selected Readings, ed. by J.B. Pride and Janet Holmes (Harmondsworth, England: Penguin, 1972).

82 Brian V. Street and Adam Lefstein, Literacy an Advanced Resource Book (London: Routledge, 2007), p. 42. 
of social practices that are usually carried out by Muslims. It involves Islamic ideology and dogma, because this literacy has a clear ideological foundation rooted in the scripture, and its implementation is believed to result in rewards in the afterlife. It also reflects power relation between the kyais/ulamas and santris, or teachers and students, and aims at realizing Muslim piety. Social practices such as this involve the values, attitudes, feelings, and social relations of Muslims.

As a social practice, Qur'anic literacy is one of the normative instruments of Islamic piety, which has a long history, since the revelation of the Qur'an to the Prophet Muhammad. ${ }^{83}$ In the context of Java, Qur'anic literacy became one of the benchmarks of Islamic piety. If a Muslim cannot read the Qur'an, his level of piety is suspect. Through varieties of activities such as Qur'anic recitation, lectures or teaching, and learning activities in mosques or schools, Qur'anic literacy repeatedly becomes a social practice.

As a social practice, Qur'anic literacy brings about other literate expressions, i.e. Arabic naming. It contributes to the preservation of pure Arabic names which remain dominant in the region of Lamongan and Lumajang, the traditional "homeland" of santri in Java. One hundred years ago (according to the dataset), or even long before that, pure Arabic names were widely used by the Javanese in both regions in giving names to their children.

An emotional attachment to the Qur'an is expressed through the naming of their children. There are many Arabic names taken from words or phrases in the Qur'an, such as Abdul Malik, Misbabul Munir, Luqmanul Hakim, Nurul Hayat, Khoirul Muttaqin, Izzul Muslimin, Khoirun Nisa', and others. There are several reasons for making the terms, words, or phrases in the Qur'an the names of their children: beautiful composition, beautiful meaning, pious-orientation, memorable meaning, servitude and asma' albusna, emulating the righteous, obtaining the blessings from the Qur'an, association with Islamic verses, and others.

For those who are familiar with Arabic literacy, and the mastery of Arabic at a high level, stringing words of Arabic together into a name that has a beautiful meaning is an expression of Arabic literacy. The kyais,

83 Anna M. Gade, "An Envy of Goodness Learning to Recite the Qur'an in Modern Indonesia", Ph.D. Dissertation (Chicago: The University of Chicago., 1999). 
religious families, or Santri families have long been sources of Arabic literacy that Javanese families relied upon to weave Arabic words into Arabic names that have beautiful meaning and has a strong vision towards piety. This is one form of communicative competence, ${ }^{84}$ as parents want to demonstrate their proficiency in Arabic through their children's names. Borrowing loosely from a concept of Bourdieu, the mastery in Arabic literacy is one form of capital ${ }^{85}$ that needs to be expressed, and can be expressed through naming.

\section{F. Concluding Remarks}

Based on the above discussions, we can conclude that the growth of Arabic names in Java shows a tendency towards Islamization in several ways. First, the growth of Arabic names in Java since the second half of the 20th century shows a tendency towards purification, i.e. the writing becoming closer to the original sounds of the Arabic language. Although Arabic names mixed with other linguistic resources became the name of a Javanese child, the Arabic name indicated a tendency towards purification. Like a tradition of Qur'anic recitation, in which a person can reach a high degree of qira'ah (the science of Qur'anic recitation) should be read in accordance with Tajweed and makhraj al-buruf correctly, so also writing Arabic names should also carefully follow these principles, because errors in the writing of Arabic names can result in changes of meaning of the name.

The Javanese express the increased importance of piety (especially after carrying out the Hajj) through changing how they name their children. Hajj, which is the culmination of the Islamic Five Pillars, is considered the pinnacle of piety, so that someone who has been on the hajj, often changes his or her name to reflect the change in piety. Although the tradition of name changes after the implementation of the pilgrimage has faded due to bureaucratic obstacles to name changes, devotional expression persists through the naming of their children. With the increasing levels of parents' education in Java, the level of their understanding of Islam has also increased. Parents know not to give Arabic names (either pure or mixed) to their children arbitrarily;

84 Hymes, "On Communicative Competence".

85 Bourdieu, Language and Symbolic Power. 
the Arabic names must match the correct transliteration rules. Writing Arabic names correctly will indicate the level of parents' understanding of Islam (especially Arabic/Quranic literacy). This purification has absolutely no connection with fundamentalism, but rather, indicates a kind of communicative competence ${ }^{86}$ in parents.

Secondly, the growth of Arabic names in Java since the late 1980s is characterized by the celebration of individuation, i.e. the need to be different from others in some aspects. ${ }^{87}$ Arabic names combined with other linguistic resources are making Javanese childrens' names increasingly unique and long, consisting of three or four words or more, so that almost no Javanese names since the end of 20th century are exactly alike. This is clearly different from the previous generation, which had a high level of concentration of names (that is, there are many similar names).

Individuation celebration was also marked by the unique meanings in the Arabic names that were given to Javanese children. Using increasingly widespread access to linguistic resources, meaningful words were assembled by Javanese parents as names for their children. Arabic names from the previous generation were relatively limited to the words or phrases from the Qur'an, or the history of the Prophets. However, since the 1980s, childrens' names have become more varied, with unique meanings. The celebration of this individuation parallels the logic of a capitalist society: the abundance of consumer goods provides many options that can be used to sharpen the uniqueness of each person ${ }^{88}$ or as seen in the concept by Jung, the individuation process is one of the characteristics of modern society. ${ }^{89}$ However, paraphrasing a question of Bruno Latour, ${ }^{90}$ have Javanese Muslims ever really become modern? As bearers of increasingly hybridized names, have they actually left tradition behind and embraced a purified modernity?

86 Hymes, "On Communicative Competence".

87 Robert A. Baron and Donn Byrne, Psikologi Sosial, trans. by Ratna Djuwita (Jakarta: Erlangga, 2004), p. 65.

88 Lieberson, A Matter of Taste.

89 C.G. Jung, Memperkenalkan Psikologi Analitis: Pendekatan Terbadap Ketaksadaran, trans. by Agus Cremers (Jakarta: Gramedia, 1989).

90 Latour, We Have Never Been Modern. 
Third, the growth of Arabic names in Java have increasingly catalyzed the hybridization of names, i.e. mixing several linguistic resources that represent several registers: Islamic, Javanese, and globalization. Hybridization of Javanese childrens' identities has become complex. It is represented by the growth Superhybrid names since the late 1980s. As with the mystic synthesis in Java, which was said to last for 600 years, ${ }^{91}$ the Javanese people still seek a synthesis of identity (hybridization) between Islam, Javanese, and globalization, even though times have changed and the Javanese people are experiencing a sort of purification in a religious context.

Although modern Javanese people use many diverse linguistic resources, as well as the idea of Lieberson's "the matter of taste", ${ }^{22}$ Arabic and Javanese names - as registers of Islam and tradition - have not disappeared in the naming Javanese children. This indicates that Javanese people still want to connect the vision of future with Islamic and Javanese traditions. Thus, despite many observations that Islam in Indonesia differs from that in Saudi Arabia, Arabic names in contemporary Javanese people still represent Islam, and are an important and easily identified form of Muslim communicative competence. As explained above, the growth of Arabic names in Java, in various forms and combinations, represents the Islamisation of the Javanese community: more widespread, more open to modernity, and keeping some sense of Javanese identity.

\footnotetext{
91 Ricklefs, Mystic Synthesis in Java.

92 Lieberson, A Matter of Taste.
} 


\section{BIBLIOGRAPHY}

Anderson, Benedict R. O'G, Java in a Time of Revolution: Occupation and Resistance, 1944-1946, Ithaca: Cornell University Press, 1972.

Anwar, M. Syafi'i, Pemikiran dan Aksi Islam Indonesia: Sebuah Kajian Politik tentang Cendekiawan Muslim Orde Baru, Jakarta: Paramadina, 1995.

Baron, Robert A. and Donn Byrne, Psikologi Sosial, trans. by Ratna Djuwita, Jakarta: Erlangga, 2004.

Bourdieu, Pierre, Distinction: A Social Critique of the Judgement of Taste, trans. by Richard Nice, Cambridge: Harvard University Press, 1984.

----, Language and Symbolic Power, ed. by John Brookshire Thompson, Cambridge: Polity Press, 1991.

Budiman, Arif, "From Lower to Middle Class: Political Activites Beforeand After 1988", in Democracy in Indonesia, 1950s and 1990s, ed. by J.D. Legge and David Bourchier, Clayton, Vic: Centre of Southeast Asian Studies, Monash University, 1994.

Bulliet, Richard W., Conversion to Islam in the Medieval Period: An Essay in Quantitative History, Cambridge: Harvard University Press, 1979.

Derrida, Jacques, "Signature Event Context", in Margins of Philosophy, trans. by Alan Bass, Chicago: University of Chicago Press, 1982.

----, On the Name, ed. by Thomas Dutoit, Stanford, CA: Stanford University Press, 1995.

----, The Politics of Friendship, trans. by George Collins, New York: Verso, 1997.

Fairclough, Norman, Language and Power, London: Longman, 1989.

Foucault, Michel, “The Subject and Power", Critical Inquiry, vol. 8, no. 4, 1982, pp. 777-95.

Friedman, Jonathan, Cultural Identity and Global Process, London: Sage Publications, 2000.

Gade, Anna M., "An Envy of Goodness Learning to Recite the Qur'an in Modern Indonesia", Ph.D. Dissertation, Chicago: The University of Chicago., 1999.

Geertz, Clifford, The Religion of Java, London: Free Press of Glencoe, 
The Politics of Arabic Naming and Islamization in Java

1960.

Giddens, Anthony, Modernity and Self-Identity: Self and Society in the Late Modern Age, Stanford: Stanford University Press, 1991.

Habibi, Nader, "Popularity of Islamic and Persian Names in Iran before and after the Islamic Revolution", International Journal of Middle East Studies, vol. 24, no. 2, 1992, pp. 253-60.

Hadiwidjana, R., Nama-Nama Indonesia, Yogyakarta: Spring, 1968.

Hatley, Ron, Keanekaragaman Kebudayaan Jawa, Surabaya: Universitas Airlangga, 1978.

Hefner, Robert W., "Islam, State, and Civil Society: ICMI and the Struggle for the Indonesian Middle Class", Indonesia, no. 56, 1993, pp. 1-35 [http://dx.doi.org/10.2307/3351197].

----, Geger Tengger: Perubahan Sosial dan Perkelabian Politik, Yogyakarta: LKiS, 1999.

----, Islam Pasar Keadilan: Artikulasi Lokal, Kapitalisme, dan Demokrasi, trans. by Amirudin and Asyhabuddin, Yogyakarta: LKiS, 2000.

Heryanto, Ariel, Identitas dan Kenikmatan: Politik Budaya Layar Indonesia, trans. by Eric Sasono, Jakarta: Kepustakaan Populer Gramedia, 2015.

Huntington, Samuel P., The Clash of Civilizations and the Remaking of World Order, New York: Simon \& Schuster, 1996.

Hymes, D.H., "On Communicative Competence”, in Sociolinguistics: Selected Readings, ed. by J.B. Pride and Janet Holmes, Harmondsworth, England: Penguin, 1972.

Jung, C.G., Memperkenalkan Psikologi Analitis: Pendekatan Terhadap Ketaksadaran, trans. by Agus Cremers, Jakarta: Gramedia, 1989.

Koentjaraningrat, Kebudayaan Jawa, Jakarta: Balai Pustaka, 1994.

Kratz, E.U., "Hikayat Raja Pasai: A Second Manuscript", Journal of the Malaysian Branch of the Royal Asiatic Society, vol. 62, no. 1 (256), 1989, pp. $1-10$.

Kuipers, Joel C. and Askuri, "Islamization and Identity in Indonesia: The Case of Arabic Names in Java", Indonesia, no. 103, 2017, pp. 25-49 [http://dx.doi.org/10.5728/indonesia.103.0025].

Kuntowijoyo, “Muslim Kelas Menengah Indonesia 1910-1950: Sebuah 
Pencarian Identitas", Prisma, vol. 11, 1985.

----, Perubahan Sosial dalam Masyarakat Agraris: Madura, 1850-1940, Yogyakarta: Mata Bangsa, 2002.

Kuswa, Endah, Makna Nama Orang Jawa: Kajian Semantik, Yogyakarta: Fakultas Sastra UGM, 2006.

Lambourn, Elizabeth, "Tombstones, Texts, and Typologies: Seeing Sources for the Early History of Islam in Southeast Asia", Journal of the Economic and Social History of the Orient, vol. 51, no. 2, 2008, pp. 252-86 [http://dx.doi.org/10.1163/156852008X307447].

Latour, Bruno, We Have Never Been Modern, trans. by Catherine Porter, Cambridge (Massachusetts): Harvard University Press, 1993.

Lévi-Strauss, Claude, The S avage Mind, Chicago: University Of Chicago Press, 1966.

Lieberson, Stanley, A Matter of Taste: How Names, Fashions, and Culture Change, New Haven: Yale University Press, 2000.

Nakamura, Mitsuo, "The Emergence of Islamizing Middle Class and the Dialectics of Political Islam in the New Order of Indonesia: Prelude to Formation of the ICMI", presented at the Islam and the Social Construction of Identities: Comparative Perspectives on Southeast Asian Muslims, University of Hawaii, 1993.

Pigeaud, T. G. T., 1967. Literature of Java: Catalogue Raisonné of Javanese Manuscripts in the Library of the University of Leiden and Other Public Collections in the Netherlands. The Hague: Martinus Nyhoff.

Poensen, C., "lets over Javaansche naamgeving en eigennamen [On Javanese Nameselection and Proper Names]", Mededeelingen van wege het Nederlandsche Zendelinggenootschap, vol. XIV, 1870, pp. 304-21.

Qutbuddin, Tahera, "Arabic in India: A Survey and Classification of Its Uses, Compared with Persian", Journal of the American Oriental Society, vol. 127, no. 3, 2007, pp. 315-38.

Ramage, Douglas E., Politics in Indonesia: Democracy, Islam, and the Ideology of Tolerance, New York: Routledge, 1995.

Ricklefs, M.C., A History of Modern Indonesia since c.1300, Stanford: Stanford University Press, 1993.

----, Mystic Synthesis in Java: A History of Islamization from the Fourteenth to the 
Early Nineteenth Centuries, Norwalk, Conn: EastBridge, 2006.

----, Polarising Javanese Society: Islamic and Other Visions, c. 1830-1930, Singapore: NUS Press, 2007.

----, Islamisation and Its Opponents in Java: A Political, Social, Cultural and Religious History, c. 1930 to the Present, Honolulu: University of Hawaii Press, 2012.

Rostow, W.W., The Stages of Economic Growth: A Non-Communist Manifesto, Cambridge: Cambridge University Press, 1960.

Smith-Hefner, Nancy J., "A Social History of Language Change in Highland East Java", The Journal of Asian Studies, vol. 48, no. 2, 1989, pp. 257-71 [http://dx.doi.org/10.2307/2057377].

Soeharno, A., Sistem Nama Diri dalam Masyarakat Jawa, Yogyakarta: Depdikbud, 1987.

Street, Brian V. and Adam Lefstein, Literacy an Advanced Resource Book, London: Routledge, 2007.

Suranto, A., Studi Tentang Sistem Nama-Nama Jawa, Surakarta: Fakultas Sastra UNS, 1983.

Sutherland, Heather, "Notes on Java's Regent Families: Part I", Indonesia, no. 16, 1973, pp. 113-47 [http://dx.doi.org/10.2307/3350649].

----, "Notes on Java's Regent Families: Part II", Indonesia, no. 17, 1974, pp. 1-42 [http://dx.doi.org/10.2307/3350770].

Sweeney, P.L. Amin, "The Connection between the Hikayat Raja2 Pasai and the Sejarah Melayu", Journal of the Malaysian Branch of the Royal Asiatic Society, vol. 40, no. 2 (212), 1967, pp. 94-105.

Syam, Nur, Islam Pesisir, Yogyakarta: LKiS, 2005.

Uhlenbeck, E.M., "Systematic Features of Javanese Personal Names", Word, vol. 25, nos. 1-3, 1969, pp. 321-35 [http://dx.doi.org/10.10 80/00437956.1969.11435576].

----, Studies in Javanese Morphology, The Hague: Martinus Nijhoff, 1978.

Wake, Christopher H., "Malacca's Early Kings and the Reception of Islam", Journal of Southeast Asian History, vol. 5, no. 2, 1964, pp. 104-28.

Widodo, Sahid Teguh, "Kajian Kes Nama Orang Jawa di Surakarta: 
Dinamik dan Sistem", Ph.D. Dissertation, Kedah: Universiti Utara Malaysia, 2010.

----, “Nama Orang Jawa Kontemporer", Haluan Sastra Budaya, vol. 29, no. 4, 2011.

----, "Konstruksi Nama Orang Jawa: Studi Kasus Nama-Nama Modern di Surakarta.", Humaniora, vol. 25, no. 1, 2013, pp. 82-91 [http:// dx.doi.org/10.22146/jh.v25i1.1815].

----, "Modernization of Javanese Personal Names in the North Coastal Region of Java Indonesia", Asian Journal of Social Sciences \& Humanities, vol. 2, no. 4a, 2013, pp. 42-9.

Widodo, Sahid Teguh and Kundharu Saddhono, "Petangan Tradition In Javanese Personal Naming Practice: An Ethnoliguistic Study", GEMA Online Journal of Language Studies, vol. 12, no. 4, 2012.

Widodo, Sahid Teguh, Nuraini Yussof, and Hisham Dzakiria, "Nama Orang Jawa: Kepelbagaian unsur dan maknanya", SARI: Jurnal Alam dan Tamadun Melayu, vol. 28, no. 2, 2010, pp. 259-77.

Wuthnow, Robert, The Restructuring of American Religion: Society and Faith since World War II, Princeton: Princeton University Press, 1988. 